\title{
A holy land quartet
}

\section{i. The Trinity of Being}

\author{
There is no god \\ but being-in-G $\Omega \mathrm{d}$. \\ My proof's a song \\ I heard far off \\ but did not understand \\ until I also sang. \\ There is no Christ \\ but being-with-Christ. \\ My proof's a shade \\ beside a lake \\ I did not recognise \\ until I said Good day. \\ There is no spirit \\ but being-in-the-Spirit. \\ My proof's a dove \\ beside a stream \\ whose call I did not heed \\ until I stopped to pray.
}

\section{ii. The Dream of Mary of Magdala}

It was the worst of hardships, going back. The women queuing at the village-wells pretended not to know us as we passed, the labourers who'd cheered us in the fields, the soldiers in the market-places jeered.

In sight of Nazareth, three unkempt men came running from a cave above the road and yelling Traitors! pelted us with stones. I felt so frightened then, and so confused. How could I tell them you were still alive?

I hurried, stumbling, down the rutted track, with Peter and your mother by my side. Then wheat and darnel, tossing in a field, a house with washing spread out on a wall and sombre faces silent round a hearth.

The welcome was, I think, as you'd expect. The fearful looks at mention of your name, the warning tales of more taxes, more troops, of girls seen loitering down the road at dusk, the insult whispered by a neighbour's wife.

What dare a widow say of nail-pierced feet, of grave-cloths dangling from a living man and village fishermen that talk bliss-speech when bowls lie empty in an unswept room and old men praise the ways of Abraham?
Be still, I thought, commune upon your bed, and fetched the washing in and swept the floor. You'd shared a meal, I heard, beside the lake. I learned to wait. Your words became a haze and my first blaze of happiness at you a blur.

That was, I think, a deeper dying into life. The haze was like a cloud of flying chaff I'd sieved to reach the barley's shining grain. The blur looked like the sight of falling scales I'd cleaned to reach the food-flesh of a fish.

For when last night I saw you in a dream, among the rocks, the graveyard's dusty trees, you looked me in the face, as at the first. The linen shroud in which we'd swaddled you seemed like a robe of crimson rinsed in light.

Your head, your whole body was marble-calm, like one of those small statues of the gods that Greek-tongued peddlers hawk in Galilee. But then I smelt your sweat, your body's myrrh and knew you were too human for their trays.

The guards around the tomb slept on and on, like men who cannot see you in their world. The light behind your head, the rocks and trees, was blue and gold and brightening into dawn. I looked and looked, into a gaze of love as live as you are still, my bread, my fish, my Christ.

\section{iii. Jonah}

'For God's sake, not again!' I heard him shout across the gloom, staggering as the whale shuddered, then lurched below the sea. 'Tell me, what new wickedness is blundering through the world?'

He stared at me, a lank and lean-faced man with bound-back hair as fish and seaweed swilled and foamed across the heaving floor. His voice was small, so hugely did the whale's heart thump and whoosh.

'I've heard the chariots of war,' he yelled, 'rumbling on land, as if they crushed beneath their horses' hooves and iron wheels the tender sprouts of wheat in Canaan's green and holy land.

'I've heard the dragons of destruction flying through the night, dropping their fiery excrement on village, farm and town. Fifty generations since my birth, tell me, what's changed?'

He sloshed across the floor and shoved his face so close to mine I saw the salt-streaks on his cheeks. 'Listen,' he said, 'stranger, till Mammon and the weapon-smiths are toppled from their throne,

till different faiths and peoples kneel before the God-of-gods, walled Nineveh, Jerusalem and Rome will always be at war. Shout this from the rooftops - what can a prophet do but warn?'
Author: Chris Mann ${ }^{1}$

Affiliation: ${ }^{1}$ Institute for the Study of English in Africa, Rhodes University, South Africa

Corresponding author: Chris Mann, c.mann@ru.ac.za

How to cite this article: Mann, C., 2016, 'A holy land quartet', Literator 37(1), a1272. http://dx.doi.org/10.4102/lit.

v37i1.1272

Copyright:@ $\subseteq$ 2016. The Authors. Licensee: AOSIS. This work is licensed under the Creative Commons Attribution License. 
Crack after monstrous crack of muffled thunder shook us then. Sea gurgled in, the vertebrae and rib-bones creaked and snapped. I passed right out, and when I stirred my lips were cracked and burnt.

A hot dry wind was blowing through the carcase of the whale. The strips of dark grey skin that dangled from the splintered ribs flapped like a tattered tarpaulin hung round a bomb-hit shrine.

I stepped outside. The glare was fierce, the sea had dried away, the coastline of the holy land looked like a blackened ridge.

I woke as I set out in Jonah's tracks across the burning sand.

\section{iv. Love and Evolution}

Nothing on earth can be more beautiful than love. Above war's smoking ruins, the corpses of its dead, above the shack-lands of the poor, a failed romance, love slowly lifts a battered, bloody head.

This is my faith, this makes me haunt faith's underground, so maddened that our species is so slow to learn I shake a prophet's placard at the hurrying crowds. Love each other, I cry, or bleed and burn!

\section{Author's notes}

The present village of Magdala is close to the shore of Lake Galilee and the town of Tiberius. See the painting The Resurrection by Piero della Francesca.

The old city of Nineveh is part of Mosul. On capturing Mosul, ISIS blew up the shrine to Jonah and later threatened the use of nuclear weapons. 